\title{
7 Clay Pots, Golden Rings, and Clean Upper Garments: Causality in Jaina Philosophy
}

\section{The Jaina Doctrine of Causality as Sad-Asat- Kārya-Vāda}

In his Presuppositions of India's Philosophies, Karl H. Potter systematically outlines and classifies various models of causality that have emerged in the history of Indian philosophy. ${ }^{1}$ He describes the Jaina model of causality as an attempt to steer the middle course between what are commonly referred to as two principal competing Indian philosophical doctrines on the nature of causal relations, namely, sat-kārya-vāda and asat-kārya-vāda. According to the first, an effect is a continuation of its causal base, and thus preexistent (sat-kārya) in its cause. According to the latter, an effect is a commencement of something radically new with regard to its cause, and hence not preexistent (asat-kārya) in it. A typical representative of the sat-kārya-vāda position is the philosophical school of Sāmkhya. Potter uses the standard example of the causal relation between milk and curds to explain its argument for the preexistence of the effect in its cause:

Milk, it is maintained, is the cause of curds, which is the effect. But the milk is the same stuff as the curds; it is merely transformed into a solid state, being the same material that was previously in a liquid state. The effect is already existent in the cause - in fact, it is

\footnotetext{
1 Karl H. Potter, Presuppositions of India's Philosophies (Delhi: Motilal Banarsidass, 1991, reprint 1999), 106-116. Some other introductions to the doctrine of causality in Indian philosophies that take Jaina philosophy into account are Mahesh Chandra Bhartiya, Causation in Indian Philosophy: With Special Reference to Nyāya-Vaiśeșika (Ghaziabad: Vimal Prakashan, 1973), 106-111; Surendranath Dasgupta, A History of Indian Philosophy, vol. 1 (Delhi: Motilal Banarsidass, 1975, reprint 1997), 174-175; Bimal Krishna Matilal, Logic, Language and Reality: Indian Philosophy and Contemporary Issues (Delhi: Motilal Banarsidass, 1985, 2nd ed. 1990, reprint 2008), 284-294; Roy W. Perrett, An Introduction to Indian Philosophy (Cambridge: Cambridge University Press, 2016), 155-167; Vetury Ramakrishna Rao, Selected Doctrines from Indian Philosophy (Delhi: Mittal Publications, 1987), 73-74; and Chandradhar Sharma, A Critical Survey of Indian Philosophy (Delhi: Motilal Banarsidass, 1960, reprint 1964), 151. These introductions provide broad overviews of the Jaina doctrine of causality rather than thorough analyses of how specific Jaina texts treat the topic of causality.
} 
the very same stuff as the cause, being altered merely in what we should call its "secondary" qualities. $^{2}$

Rather than being an entirely novel occurrence in relation to its cause, an effect is thus a transformation (parināma), and therefore a continuation, of its cause. ${ }^{3}$

A typical representative of the asat-kārya-vāda, on the other hand, is the philosophical school of Nyāya-Vaiśeșika. Potter explains its position in regard to the nature of causal relations with the help of two standard examples:

Where the satkāryavādin tends to unify the ultimate stuff in the universe, the asatkāryavādin multiplies the number of basic entities which enter as relata into the causal relation. [. . . ] The favorite examples offered by Naiyāyikas to illustrate the workings of causation are the production of a pot from the combination of its two halves and the production of a piece of cloth from the combination of some threads. ${ }^{4}$

2 Potter, Presuppositions of India's Philosophies, 106. See also Bhartiya, Causation in Indian Philosophy: With Special Reference to Nyāya-Vaiśeșika, 36-54; K. Chenchulakshmi, The Concept of Parināma in Indian Philosophy: A Critical Study with Reference to Sāmkhya-Yoga (New Delhi: Sundeep Prakashan, 2005); Indukala H. Jhaveri, The Sāmkhya-Yoga and the Jain Theories of Parināma (Ahmedabad: Gujarat University, 1990); Gerald James Larson, Classical Sāmkhya: An Interpretation of Its History and Meaning (Delhi: Motilal Banarsidass, 1969, 2nd ed. 1979, reprint 1998), 164-167; Gerald James Larson, "Introduction to the Philosophy of Sāṃkhya," in Encyclopedia of Indian Philosophies, vol. 4, Sāmphya: A Dualist Tradition in Indian Philosophy, eds. Gerald James Larson and Ram Shankar Bhattacharya (Delhi: Motilal Banarsidass, 1987), 65-73; and Roma Ray, “Is Parināmavāda a Doctrine of Causality?” Journal of Indian Philosophy 10, no. 4 (December 1982): 377-396.

3 Another philosophical tradition that is frequently described as a proponent of the sat-kārya$v \bar{a} d a$ model is Advaita Vedānta. In contrast to Sāṃkhya, Advaita Vedānta understands the transformation of a cause that brings about an effect to be an illusory rather than a real occurrence, and therefore substitutes parināma-vāda, the doctrine of transformation, with vivarta-vāda, the doctrine of illusion. Due to this distinct view, according to which only the "cause" is real, while the "effects" are illusory, the causal doctrine of Advaita Vedānta is often referred to as sat-kārana$v \bar{a} d a$. See, for example, Bhartiya, Causation in Indian Philosophy: With Special Reference to NyāyaVaiśeșika, 58-83; Eliot Deutsch, Advaita Vedānta: A Philosophical Reconstruction (Honolulu: East-West Center Press, University of Hawaii, 1969), 35-43; Nataliya Isayeva, Shankara and Indian Philosophy (Albany, NY: SUNY Press, 1993), 161-162; Richard King, Early Advaita Vedānta and Buddhism: The Mahāyāna Context of the Gaudapādīya Kārikā (Albany, NY: SUNY Press, 1995), 84-85; Potter, Presuppositions of India's Philosophies, 157-182; Arvind Sharma, Advaita Vedānta: An Introduction (Delhi: Motilal Banarsidass, 2004), 55-61; and J. G. Suthren Hirst, Sampara's Advaita Vedānta: A Way of Teaching (London: Routledge, 2005), 89-115.

4 Potter, Presuppositions of India's Philosophies, 111-112. See also Bhartiya, Causation in Indian Philosophy: With Special Reference to Nyāya-Vaiśeșika, 119-275; Wilhelm Halbfass, On Being and What There Is: Classical Vaiśeșika and the History of Indian Ontology (Albany, NY: SUNY Press, 1992), 57-58; ShashiPrabha Kumar, Classical Vaiśeșika in Indian Philosophy: On Knowing and What Is to Be Known (London: Routledge, 2013), 34-35; Bimal Krishna Matilal, "Causality in the 
In accordance with the examples provided, an effect is not a continuation of its cause, but rather a novel and therefore nonpreexistent event. ${ }^{5}$

Embracing continuity and novelty - the characteristic features of both abovementioned doctrines on the nature of causal relations - in a distinctly allinclusive or, better, non-one-sided (anekānta) manner, Jainism, as noted, endeavors to mediate and pacify the tension between them. ${ }^{6}$ Potter explains:

Nyāya-Vaiśeșika School,” Philosophy East and West 25, no. 1 (January 1975): 41-48; Bimal Krishna Matilal, "Naïve Realism, Nyāya Realism and the Causal Theory," in The Collected Essays of Bimal Krishna Matilal: Mind, Language and World, ed. Jonardon Ganeri (New Delhi: Oxford University Press, 2002), 97-113; Karl H. Potter, "Introduction to the Philosophy of Nyāya-Vaiseșika," in Encyclopedia of Indian Philosophies, vol. 2, Indian Metaphysics and Epistemology: The Tradition of Nyāya-Vaiśeșika up to Gañgeśa, ed. Karl H. Potter (Delhi: Motilal Banarsidass, 1977, reprint 1995), 54-68.

5 Buddhism, which rejects the possibility of anything persisting through the causal operation, is also commonly included in the group of the asat-kärya-vāda proponents, even though the doctrines of causality of certain Buddhist schools have been described as either subscribing to sat-kārya-vāda or evading both sat-kārya-vāda and asat-kārya-vāda. See Bhartiya, Causation in Indian Philosophy: With Special Reference to Nyāya-Vaiśeșika, 29-30, 88-105; K. N. Jayatilleke, Early Buddhist Theory of Knowledge (London: George Allen \& Unwin, 1963), 443-457; David J. Kalupahana, Buddhist Philosophy: A Historical Analysis (Honolulu: University of Hawaii Press, 1976), 26-35; David J. Kalupahana, Causality: The Central Philosophy of Buddhism (Honolulu: The University Press of Hawaii, 1982); Matilal, Logic, Language and Reality: Indian Philosophy and Contemporary Issues, 318; and T. R. V. Murti, The Central Philosophy of Buddhism: A Study of the Mãdhyamika System (London: George Allen \& Unwin, 1955, 2nd ed. 1970, reprint 1980), 166-178.

6 Matilal describes the non-one-sided approach of Jainism as "a resolution of the paradox of causality.” See Bimal Krishna Matilal, The Central Philosophy of Jainism (Anekānta-Vāda) (Ahmedabad: L. D. Institute of Indology, 1981), 26. See also Johannes Bronkhorst, "Jainism’s First Heretic and the Origin of Anekānta-vāda," in Jainism and Early Buddhism: Essays in Honor of Padmanabh S. Jaini, part 1, ed. Olle Qvarnström, 95-111 (Fremont, CA: Asian Humanities Press, 2003); Johannes Bronkhorst, “Anekāntavāda, The Central Philosophy of Ājīikikm?” International Journal of Jaina Studies 9, no. 1 (2013): 1-11; W. J. Johnson, “The Religious Function of Jaina Philosophy: Anekāntavāda Reconsidered,” Religion 25 (1995): 41-50; Bimal Krishna Matilal, "Anekānta: Both Yes and No?" Journal of Indian Council of Philosophical Research 8 (1991): 1-12; Satkari Mookerjee, The Jaina Philosophy of Non-Absolutism: A Critical Study of Anekāntavāda (Delhi: Motilal Banarsidass, 1944, 2nd ed. 1978); Y. J. Padmarajiah, A Comparative Study of the Jaina Theories of Reality and Knowledge (Bombay: Jain Sahitya Vikas Mandal, 1963); Tara Sethia, ed., Ahimssā, Anekānta, and Jainism (Delhi: Motilal Banarsidass, 2004); Nagin J. Shah, ed., Jaina Theory of Multiple Facets of Reality and Truth (Anekāntavāda) (Delhi: Motilal Banarsidass \& Bhogilal Leherchand Institute of Indology, 2000); Jayandra Soni, "Philosophical Significance of the Jaina Theory of Manifoldness," Philosophie aus interkultureller Sicht Philosophy from an Intercultural Perspective, ed. Notker Schneider et al., 277-287 (Amsterdam and Atlanta, GA: Rodopi, 1997); Jayandra Soni, "Kundakunda and Umāsvāti on Anekânta-vāda," in Essays in Jaina Philosophy and Religion, ed. Piotr Balcerowicz (Delhi: Motilal Banarsidass, 
[T] he relation we are concerned to analyze has to do with the relation between a substance at one moment having quality $\mathrm{A}$ and the same substance at the next moment lacking quality A and having quality B. [. . . ] Considering the relation of the substance at one moment to the substance at the next, the satkäryavādin is right, the effect is contained in the cause, but considering the relation of quality A to quality B, the asatkāryavādin is right, the effect is not contained in the cause. But furthermore, why must the [. . .] views be mutually exclusive? Cannot both be right, particularly if there is reason to believe that it will not do to separate entities into substance and quality though one may distinguish those two aspects of any entity - a different thing from separating them. This last is, in fact, what the Jain holds. ${ }^{7}$

Potter is referring to the Jaina understanding of causal relations with regard to a substance as it exists in two different moments in time. According to Jaina metaphysics, reality is constituted of an infinite number of substances (dravya), each of which possesses certain essential attributes (guna). These attributes incessantly and momentarily undergo modification in the form of arising and ceasing modes (paryāya), which Potter refers to as qualities. Substances as such are eternal and persist through these modal modifications. A substance in a particular moment in time is, thus, a continuation of the numerically identical substance that existed in the previous moment, since its substantial aspect has endured through both moments, as well as a novel event, since its modal aspect has changed from the previous to the present moment. If we take an example of a living substance (jiva) with one of its essential attributes of consciousness (cetanā), the jiv $a$ as a substance persists through the modal modification of its attribute of consciousness, whereas the modes of this attribute - as the different degrees to which consciousness is manifested - fluctuate momentarily. Furthermore, as Potter points out, a substance with its qualifiers comprises a single entity, and the various facets of its configuration can never be separated. Every substance in a temporal perspective, then, according to Jainism, embodies a compromise between sat-kārya-vāda and asat-kārya-vāda, which some scholars have referred to as sad-asat-kārya$v \bar{a} d a$ or sat-kāryāsat-kārya-vāda. ${ }^{8}$

2003), 25-35; and Himal Trikha, Perspektivismus und Kritik: Das pluralistische Erkenntnismodell der Jainas angesichts der Polemik gegen das Vaiśeşika in Vidyānandins Satyaśāsanaparīkşā, Publications of the De Nobili Research Library 36 (Vienna: Institut für Südasien-, Tibet- und Buddhismuskunde der Universität Wien, 2012).

7 Potter, Presuppositions of India's Philosophies, 114-115.

8 See, for example: Bhartiya, Causation in Indian Philosophy, 30; Chenchulakshmi, The Concept of Parināma in Indian Philosophy: A Critical Study with Reference to Sāmkhya-Yoga, 33; Jhaveri, The Sāmkhya-Yoga and the Jain Theories of Parināma, 172; Nancy McCagney, Nāgārjuna and the Philosophy of Openness (Lanham, MD: Rowman \& Littlefield, 1997), 67; Mohan Lal Mehta, Outlines of Jaina Philosophy: The Essentials of Jaina Ontology, Epistemology 
Potter, however, concludes his introductory description of the Jaina causal model with the following reservation regarding its persuasiveness: "The question about Jainism, philosophically speaking, is whether or not it constitutes a genuinely alternative position or merely an ad hoc eclecticism, and this once again, depends on how successful an analysis of relations it can provide upon close examination." ${ }^{9}$ This paper will address the question Potter poses, an unequivocal answer to which he does not provide. Rather than evaluate the credibility of the Jaina causal model as such, the intent is to thoroughly examine the coherence of the strategies that Jainas employ in order to distinguish their understanding of causality from the more dominant rival approaches and establish their position as one that reconciles them. The paper will do so through a close analysis of the Jaina accounts of the nature of causal relations, as suggested by Potter, with a particular focus on the descriptions of continuity and novelty and the relation between them.

The paper will mainly draw from Amṛtacandra Sūri’s Tattva-dīpikā (Light on Reality), a tenth-century Digambara Sanskrit commentary on Kundakunda's $\mathrm{Pa}$ vayaṇa-sāra (Essence of the Teaching), ${ }^{10}$ written in Prakrit (Jaina Śaurasenī). ${ }^{11}$ Despite the uncertainty regarding its dating, ${ }^{12}$ Kundakunda's Pavayana-sāra is undoubtedly one of the most authoritative early Digambara philosophical texts, and its systematic and comprehensive approach lays a foundation for the further

and Ethics (Bangalore: Jain Mission Society, 1954), 116; and Sharma, A Critical Survey of Indian Philosophy, 151.

9 Potter, Presuppositions of India's Philosophies, 115.

10 Pravacana-sāra in Sanskrit.

11 Amṛtacandra Sūri also wrote commentaries on the Pamcatthiya-saṃgaha (Pañcāstikāyasāra in Sanskrit; Essence of the Five Extensive Existents) and the Samaya-sāra (Essence of the Doctrine), two of Kundakunda's other influential texts, called Tattva-pradīpikā-vrtti (Exposition of the Light on Reality) and Ātma-khyāti (Declaration on the Self), respectively. For a discussion on the authorship of the texts that are ascribed to Kundakunda, see A. N. Upadhye, Śr Kundakundācārya's Pravacanasāra (Pavayanasāra): A Pro-Canonical Text of the Jainas, The Prakrit Text Critically Edited with the Sanskrit Commentaries of Amrtacandra and Jayasena and a Hindī Commentary of Pānde Hemarāja, with an English Translation of the Text, a Topical Index and the Text with Various Readings, and with an Exhaustive Essay on the Life, Date and Works of Kundakunda and on the Linguistic and Philosophical Aspects of Pravacanasāra (Agas: The Parama-Śruta-Prabhāvaka Mandal, Shrimad Rajachandra Ashrama, 1984), 23-46.

12 The dates ascribed to Kundakunda vary from the first century BCE to the sixth century CE. See Upadhye, Śrī Kundakundācārya's Pravacanasāra (Pavayaṇasāra), 10-23; and F. W. Thomas, "Introduction," in The Pravacana-sāra of Kunda-kunda Ācārya, Together with the Commentary, Tattva-dīpikā, by Amrtacandra Sūri, trans. Barend Faddegon, ed. with an introduction by F. W. Thomas (Cambridge: Cambridge University Press, 1935, new ed. New York: Cambridge University Press, 2014), xii-xix. 
understanding and explication of Jaina metaphysics. Amṛtacandra Sūri’s Tattvadipika is the first known commentary that was written on it. ${ }^{13}$ The commentary has received only scarce scholarly attention, but it is valuable for the purpose of this paper since it reflects a mature period in the development of Jaina philosophy, and thus provides a methodical and thorough treatment of Jaina metaphysics at a time when the focus of Jaina philosophy had turned significantly toward epistemology and logic. Its detailed treatment of the topic of causal relations challenges the doubt regarding the deliberation and comprehensiveness of the Jaina doctrine of causality. In the Tattva-dīpikā, Amrtacandra Sūri organizes the Pavayaṇa-sāra into three parts (śruta-skandha): 1. "Jñāna-tattvaprajñāpana" ("Exposition of the Reality of Knowledge”), 2. "Jñeya-tattva-pra jñāpana” ("Exposition of the Reality of the Knowable”), and 3. "Caraṇānusūcikācūlikā" ("Appendix with Advice on Conduct”). Concerned with metaphysics, this paper will mainly focus on the second part of the text.

\section{Outlining the Jaina Understanding of Causal Relations and Their Relata}

The Jainas maintain that all events are causally generated and that every effect (kārya) is a result of a multiplicity of causes (kāraṇa), rather than a result of a single cause. Causes that operate in the production of an effect are categorized into two basic types, namely, the internal (antar-anga) and the external (bahir-anga) causes. These are also referred to as the material/substantial causes (upādānakārana) and the auxiliary/efficient/instrumental causes (nimitta-kārana), respectively. ${ }^{14}$ The various causes operate within the confines of the basic causal model, the dynamics of which are characterized by both continuity and novelty, as noted in the previous section. Similarly to the expositions of causality put forward by the Sāṃkya and the Nyāya-Vaiśeșika traditions, Amṛtacandra Sūri provides an informative depiction of the Jaina understanding of the different aspects of causal dynamics involved in the production of an effect through the familiar example of the making of a clay pot:

So, just as, for example, when the completion (samskāra) [of the clay pot], effected (äropyamāna) by the potter, the stick, the wheel, and the rag, is present (sannidhi), the

13 Upadhye, Śrī Kundakundācārya's Pravacanasāra (Pavayaṇasāra), 94.

14 Jinendra Varṇī, ed., Jainendra Siddhānta Kośa, vol. 2 (Delhi: Bharatiya Jnanpith, 1971, 10th ed. 2014), 51. 
moment of the production (janma-kșaṇa) of the arising (vardhamāna) [clay pot] is the [same as the] moment of the annihilation (nāsa-kșana) of the clod of clay (mritpinda), and the [same as the] moment of the stability (sthiti-kșana) of the clayness (mrrttikätva), which is engaged (adhirūdha) in [both of] the two aspects (koti-dvaya), so too, when the completion [in general] effected by the internal (antar-anga) and the external (bahir-anga) causes (sādhana) is present, is the moment of the production of the subsequent mode ${ }^{15}$ (uttaraparyāya) [the same as] the moment of the annihilation of the preceding mode (prāktanaparyāya), and [the same as] the moment of the stability of the substantiality (dravyatva), which is engaged in [both of] the two aspects. ${ }^{16}$

The moment the effect, i.e., the finished clay pot, is arising, explains Amrtacandra Suri, the clod that was the clay's previous form is perishing. Jointly with the emerging of the pot and the perishing of the clod, there is further the clayness of the clay. The moments of production, annihilation, and stability thus converge in the event of the arising of the effect. The example draws a causal relation between the material substance of the clay in the time prior to the current moment, when it was still formless, and the material substance of the clay at the moment when it is just being formed into a pot. Although with the arising of a novel form, the clay suffers a change in its features, it also remains stable in its clayness, that is, in its character of being clay, which is "engaged in [both of] the two aspects," i.e., in both the production of a novel feature of clay and the annihilation of the previous one - neither of which, as Amrtacandra Sūri indicates, can take place without a certain aspect of the clay remaining stable throughout the change. Applied to the general dynamics of substances, the moment a new mode is arising, the prior mode is vanishing, yet the substantiality of the substance persists throughout the change, engaging as a support in both the production of the new and the destruction of the previous modal character of the substance.

15 In TD II.3, Amṛtacandra Sūri defines attributes as crosswise particular properties (vistāra-viśeșa), and modes as lengthwise particular properties (āyata-viśeșa), pointing to the temporal character of the latter. In TD I.10, he describes attributes as coexistent particular properties (sahabhāvi-viśeșa), indicating that, temporally speaking, attributes are coexistent with the substance they qualify. Modes, on the other hand, he describes as successive particular properties (kramabhāva-viśeșa); thus, as already indicated in the general introduction to the Jaina doctrine of causality in the first part of this paper, modes are qualifiers that are sequential, meaning that they are not coexistent with the substance, but rather arise and pass away in succession.

16 TD II.10: tathā hi yathā kulāla-daṇḍa-cakra-cīvarāropyamāṇa-saṃskāra-sannidhau ya eva vardhamānasya janma-kṣaṇaḥ sa eva mṛtpiṇ̣asya nāśa-kṣaṇaḥ sa eva ca koṭi-dvayādhirūḍhasya mṛttikātvasya sthiti-kṣaṇaḥ. tathā antar-añga-bahir-añga-sādhanāropyamāṇa-saṃskārasannidhau ya evottara-paryāyasya janma-kṣaṇaḥ sa eva prāktana-paryāyasya nāśa-kṣaṇaḥ sa eva ca koṭi-dvayādhirūḍhasya dravyatvasya sthiti-kṣaṇaḥ. 
The arising of an effect in the framework of such causal dynamics, as noted, demands the collaboration of several different causes. In the case of a substance, the above example, without specification, mentions that the arising of a new mode of a substance involves the operation of internal and external causes, whereas in the case of the clay pot, the example lists particular causes that assist its production. Specifically mentioned are the potter, the stick, the wheel, and the rag, which are all - as instruments that lie outside the substance of the clay - external or instrumental causes of the effect that is the clay pot. Commenting on Kundakunda's definition of a substance as "that which is coupled with origination, loss, and continuance (utpāda-vyaya-dhruvatva-samyukta) without leaving its own-being (aparityakta-svabhāva), endowed with attributes (gunavat) and accompanied by modes (saparyāya),"17 Amrtacandra Sūri provides another example, which elaborates on the nature of causal relations indicated in the example of the clay pot, both with regard to the variety and nature of causes involved in the causal process as well as its features of novelty and continuity. This is the example of the upper garment. Amṛtacandra Sūri says,

A substance (dravya) is that which is characterized by the diad of attributes and modes (guna-paryāya-dvaya) and the triad of origination, loss, and continuity (utpāda-vyayadhrauvya-traya), without commencing a change in its own-being (anārabdha-svabhāvabheda). Here the own-being (svabhāva) of substance means [its] connection to existence in general (astitva-sāmānyānvaya) ${ }^{18}$ Existence will be described as twofold: existence of a characteristic nature (svarūpāstitva) and existence of a common nature (sādṛśyāstitva). Origination means appearance (prādurbhāva), loss means destruction (pracyavana), and continuity means stability (avasthiti). Substance, being different from the origination, etc., or attributes and modes just as that which is to be characterized [is different] from that which characterizes (lakșya-lakșaṇa-bheda), does not undergo a change in its ownnature (svarūpa-bheda), since in its own-nature (svarūpa), the substance is suchlike (tathā-vidhatva), like an upper garment (uttarīya). Just as an upper garment that has

17 PS II.3: apariccatta-sahāveṇuppāda-vvaya-dhuvatta-saṃjuttaṃ / guṇavaṃ ca sapajjāyaṃ jam tạ̣ davvam ti vuccamti //

18 As pointed out by the anonymous reviewer of this paper, Amṛtacandra Sūri might have borrowed the term astitva from Vaiśeșika and gave it a new meaning. In his Padārtha-dharmasamgraha, Praśastapāda defines astitva as a property that, along with abhidheyatva (nameability) and jneyatva (cognizibility), belongs to all six ontological categories (padārtha). In the context of Vaiśeșika, Piotr Balcerowicz translates astitva as "existentiality," discerning it from existence as the highest universal, sattā, which is a property of the first three ontological categories (substance, quality, and action) only. See Piotr Balcerowicz, "What Exists for the Vaiśeșika?” in Logic and Belief in Indian Philosophy, ed. Piotr Balcerowicz (Delhi: Motilal Banarsidass, 2010, 2nd rev. ed., Warsaw: self-pub., 2016), 249-360. However, it should be pointed out that the term is already used by Kundakunda as well. See, for example, PS II.52. This means that Amrtacandra Sūri could also have taken the term from the text he is commenting on. 
acquired (upātta) a dirty state (malināvasthā), when washed (prakșālita), is originating (utpadyamāna) with reference to the state of not being dirty (amalāvasthā), is characterized by this origination, and in connection with this does not undergo a change in its own-nature, but by its own-nature adheres to being suchlike, so too does a substance that has acquired (samupātta) a previous state (prāktanāvasthā) in the presence of proper external effecting factors (samucita-bahir-añga-sādhana-sannidhi-sadbhāva) [acquire] a state that is diverse or greater (vicitra-bahutarāvasthāna), and, supported (anugrahīta) ${ }^{19}$ by its own-being in its capacity as own-nature, agent, and cause (svarūpa-kartr-karaṇasāmarthya) - which agrees (upāgata) with the internal efficacy (antar-añga-sādhanatā) [of the substance] - is originating with reference to the later state (uttarāvasthā), is characterized by this origination, and in connection with this does not undergo a change in its own-nature, but by its own-nature adheres to being suchlike. ${ }^{20}$

Amṛtacandra Sūri here provides an interesting set of details regarding the different causes involved in the arising of an effect. While describing the variety of causes required for a substance's acquisition of a novel state, he first says that proper external effecting factors (samucita-bahir-anga-sādhana) must be present in order for the novel state to emerge. This means that the external causal factors have an indispensable role in bringing about the arising of every effect, and that for a specific effect to arise, a set of the right external causes must be in operation. Drawing parallels with various external or instrumental causes that were mentioned as being involved in the production of a clay pot, we might here imagine a washer, water, and soap as instruments that assist the generation of the effect that is the clean upper garment. ${ }^{21}$

19 Faddegon suggests reading this as anug̣hita. See The Pravacana-sāra of Kunda-kunda Ācārya, Together with the Commentary, Tattva-dīpikā, by Amṛtacandra Sūri, trans. Barend Faddegon, ed. with an introduction by F. W. Thomas, 66, fn. 1 .

20 TD II.3: iha khalu yad anārabdha-svabhāva-bhedam utpāda-vyaya-dhrauvya-trayeṇa guṇa-paryāya-dvayeṇa ca yal lakṣyate tad dravyam. tatra hi dravyasya svabhāvo 'stitvasāmānyānvayaḥ, astitvaṃ hi vakṣyati dvividhaṃ, svarūpāstitvaṃ sādṛ́yāstitvaṃ ceti. tatrotpādạ̣ prādurbhāvaḥ, vyayaḥ pracyavanaṃ, dhrauyvam avasthitiḥ. [. . . ] na ca tair utpādādibhir guṇaparyāyair vā saha dravyaṃ lakṣya-lakṣaṇa-bhede 'pi svarūpa-bhedam upavrajati, svarūpata eva dravyasya tathā-vidhatvād uttarīyavat. yathā khalūttarīyam upātta-malināvasthaṃ prakṣālitam amalāvasthayotpadyamānam tenotpādena lakṣyate. na ca tena saha svarūpa-bhedam upavrajati, svarūpata eva tathā-vidhatvam avalambate. tathā dravyam api samupātta-prāktanāvastham samucita-bahir-angga-sādhana-sannidhi-sadbhāve vicitra-bahutarāvasthānaṃ svarūpa-karț-kara ṇa-sāmarthya-svabhāvenāntar-añga-sādhanatām upāgatenānugrahītam uttarāvasthayotpadyamānam tenotpādena lakșyate. na ca tena saha svarūpa-bhedam upavrajati, svarūpata eva tathāvidhatvam avalambate.

21 The instrumental causes mentioned so far have been all specific objects or subjects. It should be noted that in the Niyama-sāra (NS 30, 33) Kundakunda also speaks about substances as such acting as instrumental causes. He notes, for example, that the substances of the 
Even though a set of proper external causal factors is required for the arising of an effect, this alone is not sufficient for it, according to Amrtacandra Sūri. He says that in the arising of an effect, a substance is also charged with its own internal efficacy (antar-ariga-sādhanatā), pointing out that it is the combination of external causes and the internal causal power of the substance that generates an effect. In connection with this, he describes a changing substance not only as a cause (karana), but also as an agent (kartr). A substance, then, is not a passive element in the process of causation, being molded according to the operation and directive of external causal factors, but is rather an agent, an active force internally causing the arising of an effect. This means that in the case of the upper garment, the operation of the washer, the soap, the water, and any other external causes are not sufficient for the upper garment to become clean. In order for it to change from being dirty to being clean, the material substance of the upper garment itself must promote the arising of the novel event from within.

In TD II.4, Amrtacandra Sūri repeats the idea of a substance being an agent and a cause, but he adds that a substance is also a substratum (adhikarana) of the dynamics of origination, loss, and continuity. He gives the example of gold (kärtasvara), which functions as a substratum for the origination, loss, and continuity of a ring, a bracelet, yellowness, etc. (kuṇdalāngada-pittatādi), respectively. Apart from being a cause and an agent, then, a substance is, by providing a seat for the causal process to occur, also its support. Needless to say, the implication of substances being the seats of origination, loss, and continuity is that, in the Jaina doctrine of causality, the discourse on novelty and continuity between a cause and its effect refers to the relation between a substance as an internal cause and its effect - that is, between a substantial cause and its effect, rather than between an instrumental cause and its effect. ${ }^{22}$

medium of motion (dharma), the medium of rest (adharma), space (ākāśa), and time (kāla) function as the instrumental causes that assist motion (gamana), rest (sthiti), spatial immersion (avagāhana), and alteration (parivartana), respectively.

22 Bhartiya points out that Indian philosophers have tended to focus on the material rather than the instrumental/efficient cause: "We have seen that in western treatment of causation it is mainly the efficient cause that has figured. They have, for the most part, neglected material cause or the material cause has come into consideration there only secondarily, as when considering the whole cause preceding the effect, where actually the difference between the material and the efficient cause has disappeared. But when we come to the Indian treatment of causation, we find an altogether different approach in this matter. Indian thinkers, though they mostly accept the efficient cause (nimitta-kārana) as one of the causes, have not bothered much about it. Their main subject of treatment is the material cause, i.e., the matter, which, due to the activity of the efficient cause, takes a new shape. This material cause has of course appeared in 
Returning to the example of the upper garment, Amṛtacandra Sūri adds that, apart from having a capacity as an agent and a cause, a substance also has a capacity as own-nature (svarūpa). He does not define svarupa, so it is not clear what the word means in this context, but the Jainas generally understand the peculiar nature of a substance to be twofold: (1) atemporal, i.e., the specific substance-attributes-modes structure, and (2) temporal, i.e., the specific dynamics of origination, loss, and continuity. A substance, then, undergoes a causal process in its capacity of having this particular twofold character. Following this interpretation, the factor of svarūpa would be connected with own-being (svabhāva), another factor that Amrtacandra Sūri, in the example above, mentions in relation to the arising of the effect. He first emphasizes that a substance does not suffer a change in its own-being (anārabdha-svabhāva-bheda) despite its specific structure and dynamics. He then continues by saying that a substance acquires a novel state "supported by its own-being," a characteristic he defines as the substance's connection with existence in general (astitva-sāmānyānvaya), noting that existence will be explained as being of two kinds - namely, existence of a characteristic nature (svarūpāstitva) and existence of a common nature (sādŕśyāstitva). As indicated in the commentary itself, these two kinds of existence are references to PS II.4 and PS II.5, where Kundakunda says that the "being of existence (sadbhāva) is the own-being (svabhāva) of substance, with qualities [and] its own various modes, with origination, loss, and continuance at all times," 23 and that "one, omnipresent (sarva-gata) characteristic (lakșana) 'existing' (sat) belongs [. . .] to those with manifold characteristics (vividha-lakșaṇa).”24 In reference to PS II.4, Barend Faddegon notes,

Whilst here existence is said to be the innate nature of the substance, it is taught in II.5 that existence is sarva-gata, omnipresent, or belonging to everything, and is a lakșanam vividha-lakșanānām, a common characteristic of that which for the rest shows the greatest variety of characterization. This variation in expression has led the commentator to think that the author distinguishes existence-in-reference-to-the-substance or existence-ofcharacteristic-nature from existence-in-general. ${ }^{25}$

different shades in different systems of Indian philosophy"; see Bhartiya, Causation in Indian Philosophy, 27. See also Padmanabh S. Jaini, “Amṛtacandra Sūri’s Exposition on Reality,” in Collected Papers on Jaina Studies, ed. Padmanabh S. Jaini (Delhi: Motilal Banarsidass, 2000, reissued 2010), 48-49.

23 PS II.4: sabbhāvo hi sahāvo guṇehiṃ saha pajjaehim cittehim / davvassa savva-kālaṃ uppāda-vvaya-dhuvattehim //

24 PS II.5: [. . .] viviha-lakkhaṇāṇaṃ lakkhaṇam egạ̣ sad iti savva-gayaṃ /

25 The Pravacana-sāra of Kunda-kunda Ācārya, Together with the Commentary, Tattva-dīpikā, by Amṛtacandra Sūri, trans. Barend Faddegon, ed. with an introduction by F. W. Thomas, 67, fn. 1. 
This is a very important observation. It seems to me, however, that Amrtacandra Sūri, rather than equating existence of a common nature with existence in general as opposed to existence of a characteristic nature, as indicated by Faddegon, draws a distinction between existence of a characteristic nature (existence of individual substances with their specific structure and dynamics) and existence of a common nature (what he calls the asti, "it is," of every substance), which he understands as two kinds of existence in general. Following this, it would then be the twofold existence in general that, according to Amrtacandra Sūri, a substance by never undergoing a change in its own-being - maintains a connection with. According to this interpretation, the first type of existence, namely, the existence of a characteristic or peculiar nature, is the one connected with the own-nature (svarūpa) of a substance. A substance never loses its peculiar structure and dynamics, and, further, it employs the capacity of its very nature to propel and configure the causal process. A substance, likewise, never loses its connection with the second type of existence, that is, with existence of a common nature or the basic "it is," and this eternality holds despite and throughout its structure and dynamics.

The example of the upper garment further underscores the eternality of a substance with the description of the relationship between a substance on the one hand and origination, loss, and continuity as well as attributes and modes on the other. Amrrtacandra Sūri explains that this relationship is like that between the characterized (lakșya) and the characterizing (lakșana). The idea that a substance is characterized by origination, loss, and continuity, as well as attributes and modes, first indicates that a substance, qualities, and modes as well as origination, loss, and continuity do not exist separately, but rather in a relationship of mutual dependence, since the characterized needs something that characterizes it and the characterizing needs something to characterize. They thus exist as an entity of one (the characterized) and many (the characterizing). ${ }^{26}$ It also indicates that a substance, as that which is characterized,

26 In Tattva-pradīpikā, his commentary on the Pamcatthiya-samgaha, Amṛtacandra Sūri explains the relationship between a substance and its attributes and modes: "A substance (dra$v y a$ ) is not separated from [its] modes (paryāya) like cow's milk (go-rasa) is [not] separated from the milk [which has been milked out] (dudgha), curd (dadhi), butter (navanita), ghee (ghrta), etc. The modes are not separated from the substance like the milk [which has been milked out], curd, butter, ghee, etc. are [not] separated from cow's milk. [. . .] Attributes (guna) do not exist without a substance (dravya) like touch (sparśa), taste (rasa), smell (gandha), and colour (varna) are [not] separated (prthagbhūta) from [the substance of] matter (pudgala). The substance does not exist without attributes like [the substance of] matter is [not] separated from touch, taste, smell, and color.” (TP 12-13: atra dravya-paryāyāṇām abhedo nirdișțaḥ. dugdha-dadhi-navanīta-ghṛtādi-viyuta-gorasavat paryāya-viyutam dravyaṃ nāsti. 
cannot be something that characterizes at the same time. The characterizing function is reserved for the qualifiers of a substance and the three features of its dynamics. In the same way, the factors that characterize a substance cannot perform the function of a substance as that which is characterized. The specific functions of the characterizing and the characterized are thus fixed and noninterchangeable.

The notion that a substance is characterized by origination, loss, and continuity, as well as attributes and modes, further indicates that despite undergoing its particular dynamics and having a specific structure, a substance never radically commits to any of its individual features. Amrtacandra Sūri says that a substance does not undergo a change in its own-nature (according to the above interpretation, its particular structure and dynamics), because the manner of the operation of its own-nature is being suchlike (tattha-vidhatva). This term expresses that a substance is never only origination, only loss, only continuity, only an attribute, or only a mode, but is rather characterized by these individual features without losing any other aspects of its own-nature. The above example focuses on the feature of origination. In the rest of TD II.3, Amrtacandra Sūri applies the same logic to loss and continuity, as well as attributes and modes. In the specific case of the upper garment, he says that the upper garment is simultaneously (eka-kāla) originating with reference to being clean (amala), undergoing loss with reference to being dirty (malina), and being continuous with reference to the constant state of being a garment, that is, its garmentness (uttariyatva). It is also characterized by attributes and modes. It does not, however, experience a change in its own-nature as the upper garment, be it due to a certain feature of its dynamics or to an aspect of its structure. Likewise, says Amrtacandra Sūri, a substance, simultaneously originating with reference to the subsequent mode, undergoing loss with reference to the previous mode, and being continuous with reference to the constant state of being a substance, that is, its substantiality (dravyatva), as well as being qualified by attributes and modes, does not experience a change in its own-nature because of any of these individual features. A substance continues to exist eternally despite being characterized by various qualifiers as well as the dynamics of origination, loss, and continuity. It, further, never loses its specific structure and dynamics.

gorasa-viyukta-dugdha-dadhi-navanīta-ghṛtādivad dravya-viyuktāḥ paryāyā na santi. [. . .] pudgala-pṛthagbhūta-sparśa-rasa-gandha-varṇavad dravyeṇa vinā na guṇạ̣ saṃbhavanti. sparśa-rasa-gaṃdha-varṇa-pṛthagbhūta-pudgalavad guṇair vinā dravyaṃ na saṃbhavati.) 


\section{Novelty and Continuity in the Jaina Causal Model}

The notion of the nonradical commitment of a substance to any of the features that characterize it, as discussed above, emphasizes that with regard to both novelty (origination and loss) and continuity, a substance can only be suchlike - that is, like them or characterized by them, but never wholly any one of them. In regard to the arising of an effect, this means that an effect can never be a wholly novel product, as the Nyāya-Vaiśeșika would have it. Amṛtacandra Sūri further elaborates on this issue with reference to collections of substances as well as with reference to substances as individual entities. With reference to collections of substances, he emphasizes that substances cannot produce another substance:

Substances (dravya) do not produce (ārambha) other substances (dravyāntara), because all substances (sarva-dravya) are established through their own-being (svabhāva-siddhatva). Their being established through their own-being is due to their having neither beginning nor end (anādi-nidhanatva). Something with no beginning or end (anādi-nidhana) does not require another cause (sādhanāntara). It is an existent with its establishment established (siddha-siddhimad-bhūta) by itself (svayam), by means (upādāya) of the basic cause (mūlasädhana), the own-being of the self (ätman), which is the self of the attributes and modes. That, however, which is produced by substances, is not another substance but a mode (paryāya), because of its state of occurring occasionally ( $k \bar{a} d \bar{a} c i t k a t v a)$, like a double atom (dvyanuka), etc., and a human (manușya), etc. A substance, however, being interminable (anavadhi) and constant in the three times (trisamayāvasthāyin), could not be such. ${ }^{27}$

Amṛtacandra Sūri here points out that a substance is always established by itself (svayam) through the basic cause (mūla-sādhana) that is its own-being (svabhāva), which was defined above as the substance's connection with twofold existence in general. A substance, then, is established through itself as an existent and, as such, can never be established by another cause (sādhanāntara), such as, for example, by other substances. Amṛtacandra Sūri explains that this is due to the fact that a substance is without a beginning and without an end. Since it is eternal, nothing could have produced it and nothing could ever make it cease to be. Hcontinues by saying that while substances do not produce other substances, they do produce modes (paryāya). He gives two examples of collections of substances to illustrate this: first, a double atom, which represents a collection of two substances

27 TD II.6: na khalu dravyair dravyāntarāṇām ārambhaḥ, sarva-dravyāṇāṃ svabhāva-siddha tvāt. svabhāva-siddhatvaṃ tu teșām anādi-nidhanatvāt. anādi-nidhanaṃ hi na sādhanāntaram apekșate. guṇa-paryāyātmānam ātmanạ̣ svabhāvam eva mūla-sādhanam upādāya svayam eva siddha-siddhimad-bhūtam vartate. yat tu dravyair ārabhyate na tad dravyāntaraṃ kādācitkatvāt sa paryāyaḥ. dvyaṇukādivan-manuṣyādivac ca. dravyạ̣ punar anavadhi trisamayāvasthāyi na tathā syāt. 
of the same kind (material), and then a human, which represents a collection of two substances of a different kind (material and nonmaterial). Amrtacandra Sūri says that such collections of substances ought not to be considered as new substances, but rather as modes, because they occur only occasionally, and thus exist temporarily. In contrast to this, a substance as such, he emphasizes, never ceases to be, its constancy pervading the three times of past, present, and future.

Amrtacandra Sūri also expands on the claim that an effect can never be a wholly novel product with reference to substances as individual entities either. The notion that origination, loss, and continuity should never be thought of as occurring with reference to substances as such was already indicated in the characterizing-characterized distinction mentioned above. In the case of origination, it is never the whole substance that originates; in the case of loss, it is never the whole substance that undergoes loss; and in the case of continuity, it is never the whole substance that is continuous. Following Kundakunda, Amrtacandra Sūri develops this idea further by saying that origination, loss, and continuity are all in modes (paryāya). It should be pointed out that these are modes of a single substance, rather than modes as collections of substances discussed above. In reply to Kundakunda's assertation - "Origination, stability, and decay (utpāda-sthiti-bha $\dot{n} g a$ ) are in modes (paryāya). Modes are always a substance (dravya). Therefore, all is a substance" ${ }^{28}$ - Amrtacandra Sūri comments, "Origination, loss, and continuity (utpāda-vyaya-dhrauvya) rest on modes (paryāya), and these modes rest on a substance. Therefore all (samasta) this is one substance (dra$v y a$ ), and there is no other substance."29 The idea that the triple dynamics of origination, loss, and continuity rest on modes, and that these modes, in turn, rest on a substance, recalls the passage from TD II.4 in which Amrtacandra Sūri describes a substance as a substratum of the dynamics of origination, loss, and continuity. Because a substance is a substratum of modes, it is also a substratum of the dynamics of these modes. A substance cannot, as a whole, be affected by these dynamics, since the dynamics occur only in the modal aspect of a substance. Amrtacandra Sūri further argues in support of this idea by systematically listing the unacceptable consequences of origination, loss, and continuity occurring with respect to substances rather than their modes. He says:

But if decay, origination, and continuity (bhanga-utpāda-dhrauvya) were maintained as being of substance (dravya), then all (samgrama) would fall into confusion.

28 PS II.9: uppāda-țthidi-bhaṃgā vijjaṃte pajjaesu pajjāyā / davvaṃ hi saṃti ṇiyadaṃ tamhā davvam havadi savvam //

29 TD II.9: utpāda-vyaya-dhrauvyāṇi hi paryāyān ālambante, te punạ̣ paryāyā dravyam ālambante. tatạ samastam apy etad ekam eva dravyaṃ na punar dravyāntaram. 
In the case of decay, there would be the occurrence of the emptiness of all substances (dravya-śūnyatāvatāra), because of the dissolution (sampharana) of all substances (sarva-dravya), leered at by momentary decay (kṣaṇa-bhanga-kațākșita), in a single moment (eka-kșana), and [so] there would be utter destruction (samuccheda).

In the case of origination, there would be, for every single one (pratyeka), an infinity (anantya) of substances, marked with origination in every moment (prati-samayotpādamudrita), and [so] there would be the origination of a nonexistent (asad-utpāda).

In the case of continuity, there would be the nonexistence ( $a b h \bar{a} v a$ ) of substance because of the nonexistence of successively existing (krama-bhū) existences (bhāva), and [so] there would be momentariness (kṣaṇikatva). ${ }^{30}$

First, Amrtacandra Sūri states that if decay occurred with regard to substances as such rather than their modes, all substances would be destroyed in a single moment. Since Jaina metaphysics considers modal decay to happen momentarily, as was noted in the first part of this paper, these momentary dynamics would, when applied to substances as wholes, result in an immediate decay of all substances. This means that there would be, as Amrtacandra Sūri concludes in the section on decay, "utter destruction (samuccheda)," namely, a destruction of all there is, because all existence is, according to the Jainas, expressed through substances. Since the Jainas deem every substance to be eternal rather than momentary and liable to complete destruction, this is an unacceptable consequence for them, and so they cannot subscribe to the idea of decay occurring with regard to substances as such rather than their modes.

Second, if origination happened with regard to substances as such rather than their modes - that is, if origination were a completely novel event - every single substance would be followed by another substance every single moment, according to Amṛtacandra Sūri, since origination, in the Jaina metaphysical system, is a momentary occurrence, like decay. The result would be an infinite number of substances being produced with reference to every single substance. This is again an unacceptable consequence for the Jainas, not only because some substances in the Jaina metaphysical system (such as space and the media of motion and rest) are singular in number, but primarily because, as Amrtacandra Sūri emphasizes in his conclusion to the section on origination, "there would be an origination of a nonexistent (asad-utpāda)." As noted

30 TD II.9: yadi punar bhangotpāda-dhrauvyāṇi dravyasyaiveșyante tadā samagram eva viplavate. tathāhi bhange tāvat kṣaṇa-bhanga-kațākṣitānām eka-kṣaṇa eva sarva-dravyāṇāṃ saṃharaṇād dravya-śūnyatāvatārah samucchedo vā. utpāde tu pratisamayotpāda-mudritānāṃ pratyekaṃ dravyānām anantyam asad-utpādo vā. dhrauvye tu krama-bhuvāṃ bhāvānām abhāvād dravyasyābhāvaḥ kṣaṇikatvaṃ vā. 
above, all substances are understood to be eternal and self-established, which means that a new substance cannot be produced. A nonexistent substance cannot become existent. For that reason, the Jainas cannot subscribe to the idea of origination occurring with regard to substances as such rather than their modes.

Third, if continuity existed with regard to substances as such rather than their modes, substances would not even exist, says Amṛtacandra Sūri. For him, the concepts of continuity and eternality are clearly not the same, a notion that was already implicit in his differentiation between substantiality and substance, clayness and clay, yelowness and gold, and garmentness and garment in the examples above. ${ }^{31}$ A substance that is solely eternal could be considered to be unchanging, whereas a substance that is both eternal and continuous could not be so. Amrtacandra Sūri points out that for something to exist as being characterized by continuity, it also needs to be characterized by variance, through which only continuity can manifest itself. As noted in the example of the clay pot discussed at the beginning of the second part of this paper, this is true in the case of the continuously arising and decaying modal modifications that qualify an eternal substance. Through the arising and ceasing modes, the continuity of a substance (that is, its substantiality) as persisting through the change is manifested. The case of substances that are as such characterized by continuity is different, though, because they cannot as such simultaneously be characterized by decay and origination, the possibilities that Amṛtacandra Sūri just refuted. Their continuity can therefore not be established. The result, says Amrtacandra Sūri, is momentariness (kșanikatva), indicating a (Buddhist) notion of reality where momentary events exist without a substantial substratum. A substance characterized as a substance by continuity only would thus not exist, which is, as already noted, an unacceptable consequence for the Jainas. This means that the Jainas cannot subscribe to the idea of continuity occurring with regard to substances as such rather than their modes.

In the example of the clay pot, Amrtacandra Sūri highlighted that continuity supports both origination and annihilation. In the last excerpt, he pointed out that not only do origination and annihilation depend on continuity, but continuity too depends on origination and annihilation. In glossing Kundakunda's dictum, "There is no arising (bhava) deprived of decay (bhanga-vihina), nor is there

31 Cf. Bimal Krishna Matilal, "Ontological Problems in Nyāya, Buddhism and Jainism: A Comparative Analysis," Journal of Indian Philosophy 5 (1977): 100-101. 
decay deprived of origination. Moreover, origination (utpāda) and decay are not without a continuous object (dhrauvyārtha)," ${ }^{32}$ he further emphasizes the total interconditionality of the triple dynamics of origination, loss, and continuity with the following elaboration:

There is no creation (sarga) without dissolution (samhāra) and no dissolution without creation, no creation nor dissolution (srsțit-samhāra) without stability (sthiti), and no stability without creation and dissolution. Creation is dissolution, dissolution is creation, creation and dissolution are stability, and stability is creation and dissolution. For instance, the creation of the pot (kumbha) is the dissolution of the clod of clay (mrtpinda), because being (bhāva) becomes manifest (avabhāsana) through the own-being of the nonbeing of another being (bhāvāntarābhāva-svabhāva). And the dissolution of the clod of clay is the origination of the pot, because nonbeing ( $a b h \bar{a} v a$ ) becomes manifest through the own-being of the being of another being (bhāvāntara-bhāva-svabhāva). And the creation and dissolution of the pot and the clod are the stability of the clay (mrttikāa), because the constant (anvaya) manifests (prakāsana) through the divergences (vyatirekamukha). And the stability of the clay is the creation and dissolution of the pot and clod, because the divergences do not surpass (anatikramana) the constant. ${ }^{33}$

In several ways, this excerpt recalls the example of the clay pot. As in the clay pot example, here too Amrtacandra Sūri emphasizes that the arising of the effect that is the clay pot is also the annihilation of the clod of clay, and that the stability of the clay, that is, its clayness, pervades both. He expands on the previous example by making the additional statements that the annihilation of the clod of clay is the origination of the clay pot, and that the origination of the clay pot and the annihilation of the clod of clay are both the stability of the clay. This highlights a relationship of complete interconditionality between the three aspects of the causal process. It is not only that origination, annihilation, and stability coincide by occurring in the same moment, as was demonstrated in the example of the clay pot. No one of them could ever even occur without the others. This

32 PS II.8: ṇa bhavo bhaṃga-vihīṇo bhaṃgo vā ṇatthi saṃbhava-vihīṇo / uppādo vi ya bhamgo ṇa vin̄ā dhovveṇa atthena //

33 TD II.8: na khalu sargah saṃhāram antareṇa, na saṃhāro vā sargam antareṇa, na ș̣̦tịi-sa ṃhārau sthitim antareṇa, na sthitị̣ sarga-saṃhāram antareṇa. ya eva hi sargaḥ sa eva saṃhāraḥ, ya eva saṃhāraḥ sa eva sargaḥ, yāv eva sarga-saṃhārau saiva sthitị̣, yaiva sthitis tāv eva sargasaṃhārāv iti. tathāhi ya eva kumbhasya sargaḥ sa eva mṛtpiṇḍasya samhārạ̣ bhāvasya bhāvāntarābhāva-svabhāvenāvabhāsanāt. ya eva ca mṛtpiṇ̣asya saṃhāraḥ, sa eva kumbhasya sargaḥ, abhāvasya bhāvāntara-bhāva-svabhāvenāvabhāsanāt. yau ca kumbha-piṇụayoḥ sarga-saṃ hārau saiva mṛttikāyāḥ sthitiḥ, vyatireka-mukhenaivānvayasya prakāśanāt. yaiva ca mṛttikāyāḥ sthitis tāv eva kumbha-piṇụayoḥ sarga-saṃhārau, vyatirekāṇām anvayānatikramaṇāt. 
means that all the aspects of the causal process essentially support one another. Without annihilation, there would be no origination; without origination, no annihilation; without stability, no origination or annihilation; and without origination and annihilation, no stability. This is so, explains Amrtacandra Sūri, because being (bhāva) can become manifest only through the own-being of the nonbeing of another being (bhāvāntarābhāva-svabhāva). It is only in the passing away of an old mode that a new mode can arise. Similarly, nonbeing (abhāva) can become manifest only through the own-being of the being of another being (bhāvāntara-bhāva-svabhāva). An old mode can cease only in the arising of a new mode. This exchange, says Amrtacandra Sūri, supports stability, because, as noted, something can become manifest as stable or continuous only through divergences. While necessitating divergences, stability at the same time supports these divergences, says Amṛtacandra Sūri, since they do not surpass it; namely, they never go beyond it, but rather occur within the limits of and in coordination with it.

Similarly to the excerpt above that discussed the notion of origination, annihilation, and continuity occurring with regard to substances as such, here too Amrtacandra Sūri lists a series of unacceptable consequences of origination, annihilation, and continuity being independent from one another rather than being in a relationship of interconditionality. He says,

However, should this not be accepted in this way, it follows that creation is reduced to being something different, dissolution to being something different, and stability to being something different.

If it be so, since there is no cause for the originating (utpādana-kāranāahhāva) of the pot (kumbha), aiming at creation (sarga) only, there would be either no coming into being (abhavani) or the origination of a nonexistent (asad-utpāda).

In the case of a pot not coming into being, there would be no coming into being of anything.

In the case of the origination of a nonexistent, there would be the origination of sky flowers (vyoma-prasava), etc. ${ }^{34}$

Focusing first on origination as an independent occurrence, Amṛtacandra Sūri points out two unacceptable consequences. First, he says, there would be no coming into being (abhavani) of anything at all, indicating that nothing can originate

34 TD II.8: yadi punar nedam evam iṣyeta tadānyah sargo 'nyạ̣ saṃhārạ̣ anyā sthitir ity āyāti. tathā sati hi kevalaṃ sargaṃ mṛayamāṇasya kumbhasyotpādana-kāraṇābhāvād abhavanir eva bhavet asad-utpāda eva vā. tatra kumbhasyābhavanau sarveșām eva bhāvānām abhavanir eva bhavet. asad-utpādo vā vyoma-prasavādīnām apy utpādaḥ syāt. 
by itself. This follows his premise that it is only in being conditioned by the passing away of an old mode, on the one hand, and being conditioned by continuity on the other that a new mode can originate. If this holds for one particular existent, like a pot, argues Amṛtacandra Sūri, it also holds for every other existent, since the metaphysical structure of existence is universal according to the Jainas. So if the pot does not come into being, then nothing comes into being. The other unacceptable consequence is the origination of a nonexistent (asad-utpāda), which is the same unacceptable consequence that was listed in the abovementioned scenario of origination occurring with regard to substances as such, i.e., as substances. If one were to think of origination as something independent not in terms of modes (which seems to be the aim of the first part of the argument here), but in terms of substances, one would arrive at a paradoxical situation, because, as noted, something that cannot be produced (i.e., a nonexistent) would be produced. Amrtacandra Sūri says that this would be like the origination of sky flowers, a common example Indian philosophers use to depict a nonexistent.

He continues his argument by focusing on annihilation as an independent occurrence:

Likewise, since there is no cause for the dissolution (saṃhāra-kāranāah āva) of the clod of clay (mrtpinda), which is undergoing dissolution only, there would be either no dissolution (asamharani) or a destruction of an existent (sad-uccheda).

In the case of the clod of clay not undergoing dissolution, there would be no dissolution of anything.

In the case of the destruction of an existent, there would be a destruction of consciousness (samvid), etc. ${ }^{35}$

If annihilation were an independent occurrence, the first unacceptable consequence, says Amrtacandra Sūri, would be that there would be no dissolution (asamharani) of anything at all, by which he indicates, similarly as in the previous case of origination, that annihilation cannot happen by itself. This again follows his premise that it is only being conditioned by the origination of a new mode on the one hand, and by continuity on the other, that an old mode can be annihilated. Again, if this holds for one particular existent, like a clod of clay, argues Amrtacandra Sūri, it also holds for every other existent, since according to the Jainas - as noted above - all existents have the same metaphysical structure. So, if the clod of clay does not undergo annihilation,

35 TD II.8: tathā kevalaṃ saṃharamāṇasya mṛtpiṇụasya saṃhāra-kāraṇābhāvād asaṃharaṇir eva bhavet sad-uccheda eva vā. tatra mṛtpiṇ̣asyāsaṃharanau sarveșām eva bhāvānām asaṃharaṇir eva bhavet. sad ucchede vā saṃvid-ādīnām apy ucchedaḥ syāt. 
then nothing undergoes annihilation. The second unacceptable consequence that Amrtacandra Sūri cautions against is the destruction of an existent (saduccheda), which matches the unacceptable consequence that he posits in the case of the abovementioned idea of annihilation occurring with regard to substances as such, i.e., as substances. Similarly to the case of origination, if one were to think of annihilation as something independent not in terms of modes, but in terms of substances, one would arrive at a paradoxical situation, because, as noted, a substance as eternal cannot be annihilated. In fact, as Amrtacandra Sūri claims, the annihilation of a substance would be like the annihilation of awareness (samvid), something that is utterly unacceptable to the Jainas, as according to the Jaina metaphysics, no living being can ever completely lose their essential attribute of awareness or consciousness. Despite fluctuating in its degrees of manifestation, awareness as such is indestructible.

Amrtacandra Sūri continues his list of unacceptable consequences by focusing on stability as an independent occurrence. He says,

Likewise, since there is no constant of stability, overspread with divergences (vyatirekākrānta-sthity-anvayābhāva), of the clay, [in the case of] admitting stability only, there would be either no stability (asthāni) or an eternity of the momentary (kșaṇika-nityatva).

In the case of no stability of the clay, there would be no stability of anything.

In the case of the eternity of the momentary, there would be eternity (nityatva) of the moments of citta (citta-kșana). ${ }^{36}$

According to Amrtacandra Sūri, if stability were an independent occurrence, the first unacceptable consequence would be that there would be no stability (asthāni) of anything at all. As in the previous two cases, he indicates that stability cannot occur by itself. This accords with his premise that it is only through the variation of the passing away of an old mode and the arising of a new mode that stability can be manifested. Again, if this holds for one particular existent, like clay, as Amrtacandra Sūri argues, it also holds for every other existent, since, as noted in the previous two cases, the metaphysical structure of existence is universal according to the Jainas. So if the clay is not stable, then nothing is stable.

The second unacceptable consequence that Amrtacandra Sūri lists is the eternity of the momentary (kșanika-nityatva). This formulation is similar to the

36 TD II.8: tathā kevalāṃ sthitim upagacchantyā mrttikāyā vyatirekākrānta-sthity-anva yābhāvād asthānir eva bhavet, kṣaṇika-nityatvam eva vā. tatra mṛttikāyā asthānau sarveșām eva bhāvānām asthānir eva bhavet. kṣaṇika-nityatve vā citta-kṣaṇānām api nityatvaṃ syāt. 
one that he used to express the unacceptable consequence of stability occurring with regard to substances as such, i.e., as substances. There, he said that if stability were to occur with regard to substances as such, the result would be the nonexistence of a substance and, therefore, momentariness. Here, he mentions the second part of the previous formulation only, namely, existence as momentary. He illustrates this consequence with an example of the eternality of the moments of citta (citta-kșana), something that, as noted above, is completely unacceptable to the Jainas, as according to the Jaina metaphysics, a cognitive faculty is an essential attribute, and thus a stable aspect of every living being. This means that it cannot as such be fragmented into moments, even though, as an attribute, it continually undergoes momentary modal change.

Having shown that the idea of origination, annihilation, and loss occurring independently of each other leads to unacceptable consequences and is therefore insupportable, Amṛtacandra Sūri concludes that the three are in an eternal relationship of absolute interconditionality:

Consequently, it is necessarily to acknowledge that a substance (dravya) is marked by three characteristics shining forth without interruption (uddyotamāna-nirvighna-trai-lakșanyalāñchana), unseparated (avinābhūta) from a creation of posterior divergences (uttarottaravyatireka), from a dissolution of prior divergences (pūrva-pūrva-vyatireka), and a stability (avasthāna) of the constant (anvaya). ${ }^{37}$

\section{Credibility of the Jaina Causal Model: Improvisation or Deliberation?}

Having carefully studied the Jaina doctrine of the nature of causal relations in Amrtacandra Sūri's Tattva-dipikiā, it is now possible to return to Potter's question of whether the conciliation offered by the Jaina causal model is a superficial and ad hoc or a methodical and cogent position. Following Kundakunda, Amrtacandra Sūri emphasizes that origination, loss, and continuity all belong to the same ontological plane, that is, to the modal aspect of substances. This is one way in which the idea that novelty is not subordinate to continuity nor continuity to novelty was underlined. Another approach to coordinating the two was through the notion that the modal plane is an inalienable aspect of

37 TD II.8: tata uttarottara-vyatirekāṇām sargeṇa pūrva-pūrva-vyatirekāṇām saṃhāreṇānvayasyāvasthānenāvinābhūtam uddyotamāna-nirvighna-trai-lakṣaṇya-lāñchanaṃ dravyam avaśyam anumantavyam. 
substances. Substances need modes as much as modes need substances. This gives a solid grounding to modal dynamics, meaning that origination, loss, and continuity, as belonging to modes, are all necessary aspects of every substance. That they are equally so was indicated by the idea of the momentary occurrence of origination and decay. Their momentariness ensures that novelty is not secondary to continuity, but that every single moment of every existent is a moment of the arising of an effect as a convergence of origination, loss, and continuity. This results in a causal model that not only brings together novelty and continuity, but brings them together every single moment. Furthermore, origination, loss, and continuity were emphasized as eternally being in a relationship of total interconditionality, each one of them presenting the essential condition for the arising of the other. Thus, according to the Jaina causal model, novelty and continuity condition each other, without interruption, momentarily, eternally, on the same ontological plane, which is the modal aspect of every substance. These features clearly delineate the Jaina view on causality from the rival approaches to the issue. Unlike the case of an effect of prakrti in Sāmkhya, the novelty of an effect in the Jaina causal model is not secondary but essential to the continuity itself; moreover, unlike the case of an effect in Nyāya-Vaiśeșika, the novelty of an effect in the Jaina causal model necessitates continuity in order to take place, with novelty at the same time never overriding continuity. Reading Amrtacandra Sūri's detailed exposition of the nature of causal relations and his systematic attempts to draw a balanced model that coordinates the novelty and continuity of effects with regard to their substantial causes, it is clear that it is clear that the explanations of the Jaina model of causality can certainly be deliberate, carefully articulated, and coherent.

\section{Abbreviations}

PS - Pavayaṇa-sāra (Pravacana-sāra)

TD - Tattva-dīpikā

\section{Bibliography}

Bajželj, Ana. "The Jain Ontological Model According to Kundakunda and Umāsvāti.” Asian Studies 1, no. (17)/1 (2013): 3-16.

Balcerowicz, Piotr. "The Logical Structure of the Naya Method of the Jainas." Journal of Indian Philosophy 29 (2001): 379-403. 
Balcerowicz, Piotr. “What Exists for the Vaiśeșika?" In Logic and Belief in Indian Philosophy, edited by Piotr Balcerowicz, 249-360. Delhi: Motilal Banarsidass, 2010. 2nd rev. ed., Warsaw: self-published, 2016.

Balslev, Anindita N. A Study of Time in Indian Philosophy. Delhi: Motilal Banarsidass, 2009. Bartley, Christopher. An Introduction to Indian Philosophy. London: Continuum, 2011.

Bhartiya, Mahesh Chandra. Causation in Indian Philosophy: With Special Reference to NyāyaVaiśeșika. Ghaziabad: Vimal Prakashan, 1973.

Bhatt, Bansidhar. "Vyavahāra-Naya and Niścaya-Naya in Kundakunda’s Works.” In VIII. Deutscher Orientalistentag, Vorträge, edited by Wolfgang Voigt, 279-291. Wiesbaden: Franz Steiner, 1974. Zeitschrift der Deutschen Morgenländischen Gesellschaft 28, supplement 2.

Bhattacharya, Hari Satya. Reals in the Jaina Metaphysics. Delhi: Motilal Banarsidass, 1966. Bronkhorst, Johannes. “Jainism's First Heretic and the Origin of Anekānta-vāda." In Jainism and Early Buddhism: Essays in Honor of Padmanabh S. Jaini. Part 1, edited by Olle Qvarnström, 95-111. Fremont, California: Asian Humanities Press, 2003.

Bronkhorst, Johannes. "Anekāntavāda, The Central Philosophy of Ājīvikism?” International Journal of Jaina Studies 9, no. 1 (2013): 1-11.

Chapple, Christopher Key. "Free Will and Voluntarism in Jainism." In Free Will, Agency, and Selfhood in Indian Philosophy, edited by Matthew R. Dasti and Edwin F. Bryant, 68-84. New York: Oxford University Press, 2014.

Chenchulakshmi, K. "The Concept of Pariṇāma in Indian Philosophy: A Critical Study With Reference to Sāṃkhya-Yoga.” New Delhi: Sundeep Prakashan, 2005.

Dasgupta, Surendranath. A History of Indian Philosophy. Vol. 1. 1975. Reprint, Delhi: Motilal Banarsidass, 1997.

Deutsch, Eliot. Advaita Vedānta: A Philosophical Reconstruction. Honolulu: East-West Center Press, University of Hawaii, 1969.

Dhaky, Madhusudan A. "The Date of Kundakundācārya." In Aspects of Jainology: Vol. III. Pt Dalsukhbhai Malvania Felicitation Volume I, edited by M. A. Dhaky and Sagarmal Jain, 187-206. Varanasi: P. V. Research Institute, 1991.

Dixit, K. K. Jaina Ontology. Ahmedabad: L. D. Institute of Indology, 1971.

Emmrich, Christoph. "How Many Times? Monism and Pluralism in Early Jaina Temporal Description.” In Essays in Jaina Philosophy and Religion, edited by Piotr Balcerowicz, 69-88. Delhi: Motilal Banarsidass.

Gangopadhyay, M. K. “Causality in Indian Philosophy: A Brief Survey.” In Relations in Indian Philosophy, edited by V. N. Jha, 122-140. Delhi: Sri Satguru Publications, 1992.

Glasenapp, Helmuth von. Jainism: An Indian Religion of Salvation. Delhi: Motilal Banarsidass, 1999.

Halbfass, Wilhelm. On Being and What There Is: Classical Vaiśeșika and the History of Indian Ontology. Albany, NY: SUNY Press, 1992.

Hiriyanna, M. Outlines of Indian Philosophy. Delhi: Motilal Banarsidass, 2005.

Isayeva, Nataliya. Shankara and Indian Philosophy. Albany, NY: SUNY Press, 1993.

Jaini, Padmanabh S. "Amrtacandra Sūri’s Exposition on Reality." In Collected Papers on Jaina Studies, edited by Padmanabh S. Jaini, 39-82. 2000. Reissued, Delhi: Motilal Banarsidass, 2010.

Jaini, Padmanabh S. The Jaina Path of Purification. Delhi: Motilal Banarsidass, 2001.

Jayatilleke, K. N. Early Buddhist Theory of Knowledge. London: George Allen \& Unwin, 1963. 
Jhaveri, Indukala H. The Sāṃkhya-Yoga and the Jain Theories of Parināma. Ahmedabad: Gujarat University, 1990.

Johnson, Will J. Harmless Souls: Karmic Bondage and Religious Change in Early Jainism with Special Reference to Umāsvāti and Kundakunda. Delhi: Motilal Banarsidass, 1995.

Johnson, Will J. "The Religious Function of Jaina Philosophy: Anekāntavāda Reconsidered." Religion 25 (1995): 41-50.

Kalupahana, David J. Buddhist Philosophy: A Historical Analysis. Honolulu: University of Hawaii Press, 1976.

Kalupahana, David J. Causality: The Central Philosophy of Buddhism. Honolulu: The University Press of Hawaii, 1982.

King, Richard. Early Advaita Vedānta and Buddhism: The Mahāyāna Context of the Gauḍapādīya Kārikā. Albany, NY: SUNY Press, 1995.

Kumar, ShashiPrabha. Classical Vaiśeșika in Indian Philosophy: On Knowing and What Is to Be Known. London: Routledge, 2013.

Kundakunda. [Niyama-sāra] 1. Niyamasāra: Śrīmad Padmaprabha Maladhārīdeva Tātparyavrtti nāmaka saṃskrta țīkā sahita, ed. and trans. Hukamacanda Bhārilla. Jaipur: Paṇ ḍit Ṭọ̣armal Sarvodaya Ṭrașt, 1960. 2. Niyamasāra, trans. Uggar Sain. New Delhi: Bharatiya Jnanpith, 2006.

Kundakunda. [Paṃcatthiya-saṃgaha/Pañcāstikāya-sāra]. 1. Śrīmat-Kundakunda-svāmiviracitạ̣ Pañcāsti-kāyaḥ Tattva-pradīpikā-Tātparya-vṛtti-Bālāvabodhaka-bhāṣeti țīkātrayopetah, edited by Manoharlāl. Agās: Śrīmad Rājacandra Āśrama, 1998. 2. Ācārya Kundakunda's Pañcāstikāya-sāra (The Building of the Cosmos), edited by A. N. Upadhye, translated by A. Chakravarti Nayanar. New Delhi: Bharatiya Jnanpith, 2001.

Kundakunda. [Pavayaṇa-sāra/Pravacana-sāra] 1. Śrī Kundakundācārya's Pravacanasāra (Pavayanasāra): A Pro-Canonical Text of the Jainas, The Prakrit Text Critically Edited with the Sanskrit Commentaries of Amrtacandra and Jayasena and a Hindī Commentary of Pānde Hemarajja, with an English Translation of the Text, a Topical Index and the Text with Various Readings, and with an Exhaustive Essay on the Life, Date and Works of Kundakunda and on the Linguistic and Philosophical Aspects of Pravacanasāra by A. N. Upadhye, edited and translated by A. N. Upadhye. Bombay: The Parama-ŚrutaPrabhāvaka Maṇdala, 1935. 2. The Pravacana-sāra of Kunda-kunda Ācārya, Together with the Commentary, Tattva-dīpikā, by Amrtacandra Süri, translated by Barend Faddegon, edited with an introduction by F. W. Thomas. Cambridge: Cambridge University Press, 1935. New ed. New York: Cambridge University Press, 2014.

Kundakunda. [Samaya-sāra]. 1. Samayasāra, ed. and trans. Pannālāl Jain. Rāyacandra Jaina Śāstra Mālā Series 14. Agās: Śrīmad Rājacandra Āśrama, 1919. 2. Ācārya Kundakunda's Samayasāra, ed. and trans. A. Chakravarti. New Delhi: Bharatiya Jnanpith, 2008.

Larson, Gerald James. "Introduction to the Philosophy of Sāṃkhya." In Encyclopedia of Indian Philosophies, vol. 4, Sāṃkhya: A Dualist Tradition in Indian Philosophy, edited by Gerald James Larson and Ram Shankar Bhattacharya, 3-103. Delhi: Motilal Banarsidass, 1987.

Larson, Gerald James. Classical Sāṃkhya: An Interpretation of Its History and Meaning. 1969. 2nd ed. 1979. Reprint, Delhi: Motilal Banarsidass, 1998.

Long, Jeffery D. Jainism. London and New York: I. B. Tauris, 2009.

Matilal, Bimal Krishna. "Causality in the Nyāya-Vaiśeșika School." Philosophy East and West 25, no. 1 (January 1975): 41-48.

Matilal, Bimal Krishna. "Ontological Problems in Nyāya, Buddhism and Jainism: A Comparative Analysis.” Journal of Indian Philosophy 5 (1977): 91-105. 
Matilal, Bimal Krishna. The Central Philosophy of Jainism (Anekānta-vāda). Ahmedabad:

L. D. Institute of Indology, 1981.

Matilal, Bimal Krishna. “Anekānta: Both Yes and No?” Journal of Indian Council of

Philosophical Research 8 (1991): 1-12.

Matilal, Bimal Krishna. "Naïve Realism, Nyāya Realism and the Causal Theory." In The Collected Essays of Bimal Krishna Matilal: Mind, Language and World, edited by Jonardon Ganeri, 97-113. New Delhi: Oxford University Press, 2002.

Matilal, Bimal Krishna. Logic, Language and Reality: Indian Philosophy and Contemporary Issues. 1985. 2nd ed. 1990. Reprint, Delhi: Motilal Banarsidass, 2008.

McCagney, Nancy. Nāgārjuna and the Philosophy of Openness. Lanham, MD: Rowman \& Littlefield, 1997.

Mehta, Mohan Lal. Outlines of Jaina Philosophy: The Essentials of Jaina Ontology, Epistemology and Ethics. Bangalore: Jain Mission Society, 1954.

Mehta, Mohan Lal. Jaina Philosophy: An Introduction. Bangalore: Bharatiya Vidya Bhavan, 1998.

Mookerjee, Satkari. The Jaina Philosophy of Non-Absolutism: A Critical Study of Anekāntavāda. 1944. 2nd ed. Delhi: Motilal Banarsidass, 1978.

Murti, T. R. V. The Central Philosophy of Buddhism: A Study of the Mādhyamika System. 1955. 2nd ed. 1970. Reprint, London: George Allen \& Unwin, 1980.

Padmarajiah, Y. J. A Comparative Study of the Jaina Theories of Reality and Knowledge. Bombay: Jain Sahitya Vikas Mandal, 1963.

Perrett, Roy W. An Introduction to Indian Philosophy. Cambridge: Cambridge University Press, 2016.

Potter, Karl H. "Introduction to the Philosophy of Nyāya-Vaiśeșika." In Encyclopedia of Indian Philosophies, vol. 2, Indian Metaphysics and Epistemology: The Tradition of Nyāya-Vaiśeșika up to Gañgeśa, edited by Karl H. Potter (general editor Karl H. Potter), 1-208. 1977. Reprint, Delhi: Motilal Banarsidass, 1995.

Potter, Karl H. Presuppositions of India's Philosophies. 1991. Reprint, Delhi: Motilal Banarsidass, 1999.

Pūjyapāda. [Sarvārtha-siddhi] Reality: English Translation of Shri Pujyapada's Sarvarthasiddhi, trans. S. A. Jain. Calcutta: Vira Sasana Sangha, 1960.

Ramaiah, C. The Problem of Change and Identity in Indian Philosophy. Tirupati: Sri Venkateswara University, 1978.

Rao, Vetury Ramakrishna. Selected Doctrines from Indian Philosophy. Delhi: Mittal Publications, 1987.

Ray, Roma. “Is Parināmavāda a Doctrine of Causality?” Journal of Indian Philosophy 10, no. 4 (December 1982): 377-396.

Schubring, Walther. "Kundakunda Echt und Unecht.” Zeitschrift der Deutschen Morgenländischen Gesellschaft 107 (1957): 537-574.

Schubring, Walther. The Doctrine of the Jainas, trans. Wolfgang Beurlen. Delhi: Motilal Banarsidass, 1962.

Sethia, Tara, ed. Ahimsāa, Anekānta, and Jainism. Delhi: Motilal Banarsidass, 2004.

Shah, Nagin J., ed. Jaina Theory of Multiple Facets of Reality and Truth (Anekāntavāda). Delhi: Motilal Banarsidass \& Bhogilal Leherchand Institute of Indology, 2000.

Shaha, S. M. The Dialectic of Knowledge and Reality in Indian Philosophy. Delhi: Eastern Book Linkers, 1987.

Sharma, Arvind. Advaita Vedānta: An Introduction. Delhi: Motilal Banarsidass, 2004. 
Sharma, Chandradhar. A Critical Survey of Indian Philosophy. 1960. Reprint, Delhi: Motilal Banarsidass, 1964.

Soni, Jayandra. “Dravya, Guṇa and Paryāya in Jaina Thought." Journal of Indian Philosophy 19 (1991): 75-88.

Soni, Jayandra. "Philosophical Significance of the Jaina Theory of Manifoldness." In Philosophie aus interkultureller Sicht - Philosophy from an Intercultural Perspective, edited by Notker Schneider et al., 277-287. Amsterdam and Atlanta, GA: Rodopi, 1997.

Soni, Jayandra. "Kundakunda and Umāsvāti on Anekānta-vāda." In Essays in Jaina Philosophy and Religion, edited by Piotr Balcerowicz, 25-35. Delhi: Motilal Banarsidass, 2003.

Soni, Jayendra, and Dalsukh Malvania, eds. Encyclopedia of Indian Philosophies. Vol. 10, Jain Philosophy, Part 1 (general editor Karl H. Potter). Delhi: Motilal Banarsidass, 2007.

Suthren Hirst, J. G. Śamkara's Advaita Vedānta: A Way of Teaching. London: Routledge, 2005. Tatia, Nathmal. Studies in Jaina Philosophy. Calcutta: Modern Art Press, 1952.

Thomas, F. W. "Introduction.” In The Pravacana-sāra of Kunda-kunda Ācārya, Together with the Commentary, Tattva-dīpikā, by Amrtacandra Sūri, translated by Barend Faddegon, edited with an introduction by F. W. Thomas, xii-xix. Cambridge: Cambridge University Press, 1935. New ed. New York: Cambridge University Press, 2014.

Trikha, Himal. Perspektivismus und Kritik: Das pluralistische Erkenntnismodell der Jainas angesichts der Polemik gegen das Vaiśeşika in Vidyānandins Satyaśāsanaparīkşā. Publications of the De Nobili Research Library 36. Vienna: Institut für Südasien-, Tibetund Buddhismuskunde der Universität Wien, 2012.

Tukol, T. K. Compendium of Jainism. Dharwad: Karnatak University, 1980.

Varṇī, Jinendra, ed. Jainendra Siddhānta Kośa. Vol. 2. Delhi: Bharatiya Jnanpith, 2014. 
